\title{
Introduction to the English Translation of Geometry of the Passions
}

Looking back at this book, twenty-seven years after the first Italian edition and twenty-four after the fourth revised one (Geometria delle passioni:Paura, speranza, felicità: Filosofia e uso politico, Milan, Feltrinelli, 1991 and 1994), twenty-three years after two Spanish translations (Geometría de las pasiones: Miedo, esperanza, felicidad: Filosofía y uso político, Mexico, D.F., Fundo de cultura económica, 1995; Una geometría de las pasiones: Miedo, esperanza y felicidad: filosofía y uso político, Barcelona, Muchnik Editores, 1995), and twenty-one years after the French (Géométrie des passions: Peur, espoir, bonheur: De la philosophie à l'usage politique, Paris, Presses Universitaires de France, 1997), I do not seem to have found sufficient reason to diverge from its original formulation. For this reason, I have not modified the structure or rhythm of the discussion, which seem to me to still hold up to the wear and tear of time. Of course, the bibliography is not updated (in this translation, therefore, I have sacrificed many of the notes present in the Italian edition), but it is worth the trouble to note that this book anticipated the rage for studies on emotional intelligence or sad passions.

The years that have passed may weigh little or much. They weigh little, because philosophical works aspire to be independent of their temporal conditionings. They weigh a lot if one thinks about how these decades have been so rich in unexpected events as to have literally changed the world in which we were used to living and, therefore, our way of posing questions about it as well. In their essential nucleus, the problems discussed here should not be touched by the passage of time, and yet the tools of meaning we use to interpret things undergo endless distortions, fractures, and movements. Philosophy explores, redesigns, and illustrates the drift and the fault lines of those symbolic continents on which our common thought and feeling rests. The mental and emotional maps are transformed, like languages, in a generally slow and inexorable way, 
but only at a certain point are "catastrophic" discontinuities produced or felt that oblige us to think again about how much has happened. Ideas undergo a transformation, molecular or sudden, owing to the very distance from which one looks at the problems and at the change in the frames that surround them. They have the tendency to ferment on their own, and every investigation is therefore destined to remain incomplete. One puts an end to them because, at a certain point, one has reached a saturation phase with respect to the assembled materials and reasoning. Subsequently, however, new and relevant conceptual ramifications are inevitably discovered; there emerges, sometimes by chance, other important literature on the subjects previously addressed; and one reconsiders observations made by friends or reviewers.

Is there consequently a need to rewrite books and constantly adapt them to the changing situations and moods of the public? It would be a useless effort to follow current events ad infinitum or to believe that everything must be connected back to them. One could certainly assert that philosophies do not express eternal truths, that they are at once outdated and current, within and outside of time. The tradition of bipartition, formulated by Benedetto Croce, between "what is alive" and "what is dead" in a given work or philosophy therefore loses value. If one abandons the idea that the philosophies of the past are useful to current events, what is living and what is dead changes with every theoretical season. What is current today is already outdated tomorrow (and vice versa). Thus, even the beautiful Crocian simile expressed in La storia come pensiero e come azione (History as Thought and Action) appears reductive - i.e., that history must revive the petrified and sclerotic past "almost in the way one speaks of certain images of Christs and Madonnas, which, wounded by the words and actions of some blasphemer and sinner, issue red blood." Bringing everything back to the present, conceiving all of history as "contemporary history," means, in fact, cannibalizing the past - subordinating, in an exclusive way, its inexhaustible reserve of meaning to the transient interests of the present. It must be added that human passions and desires transform themselves in a much slower way than ideas, and they thus preserve a greater consistency and duration (which facilitates their analysis) and that, at the time I wrote Geometry of the Passions, much less had been written on the French Revolution and the Jacobins (it was then close to the Bicentennial of 1989). 
On the other hand, if what Schopenhauer asserts is true - that every one of us does nothing else for all our lives than develop a single idea every book contains within it the premises for further developments. As the Latin proverb says, habent sua fata libelli: books have their destiny; they are witnesses to a particular era. Precisely because a book contains the basis of later, distinctive developments that bear the imprint of the person who wrote it, every work is not only inherently incomplete, but it is also historically conditioned, an aspect from which one must not pull away.

I have, however, changed the perspectives of this book - elaborating, developing, and changing its contents and aims, explicit or implicit thanks to two other volumes that, along with this one, represent a sort of triptych: Ordo amoris: Conflitte terreni e felicità celeste (Bologna, Il Mulino, 1991) and Destini personali: L'età della colonizzazione delle coscienze (Milan, Feltrinelli, 2002). In my intentions, each of them should have made up part of the constellation of theoretical interests that still guide me and that focus on the genesis of Western individuality from the point of view of the formation of identity, the articulation of the passions, the succession of conflicts, the intensification of expectations of change, and the temptations of flight from the world towards the recesses of inwardness or towards the sphere of the religious dimension. I conducted an expanded reflection on the passions, and specifically on one of those most discussed since ancient Greece, in Ira: La passione furente (Bologna, Il Mulino, 2011).

In Geometry of the Passions, these subjects were addressed by placing in relief the paradoxical conflict-collaboration between passions and reason and by extending the theoretical and historical investigation across the arc of time that runs from the ancients (and relative to the moderns, from Descartes, Hobbes, and Spinoza) to the French Jacobins. In Destini personali: L'età della colonizzazione delle coscienze, on the other hand, I examined the problem of the birth of modern individuality starting from two different sources. One is represented by Locke, who emphasizes the value of the individual, laying down the foundations of the theory of human rights and political liberalism; the other is represented by Schopenhauer, for whom individuality is simply appearance, while what truly counts is the anonymous will to live that dwells within us and renders our $I$ nothing other than "a voice that resounds in a hollow sphere of glass." ${ }^{2}$ Thus, what seems most ours, the consciousness of being of an $I$ or a subject, is in reality something foreign. In this work, however, I reconstruct the 
antagonistic confluence of these two lines to the present through a series of figures that have in common the abdication of the subject and the loss of its unity, of its supremacy. In chronological terms, I did so, in particular, by considering the imprint left by some exponents of French culture of the last decades of the nineteenth century and by Nietzsche, which replace the "pyramidal" Goethian model.

In fact, the so-called French médeciens-philosophes of the late nineteenth century (Ribot, Janet, and Binet) affirm the idea that the $I$ is plural; it is composed - like coral colonies - of an original multiplicity of $I \mathrm{~s}$, which subordinate themselves to a "hegemonic $I$ " that in turn, in a "democratic" way, becomes either a sort of president or "coalition" government or, in an "autocratic" way, a sort of Louis XIV, a Moi Soleil. When the coordinating or hegemonic function of the $I$ is no longer capable of withstanding new challenges, welcoming into itself new increases in complexity, the personality (which, generally speaking, is already insufficiently coherent and lacks that unity, simplicity, and identity that philosophical and religious tradition attributes to the soul, now examined according to categories that are "scientific" and no longer theological or metaphysical) splits into independent entities. The will does not succeed, then, in maintaining its identity, torn as it is by the plurality of conflicting desires over which it has no power. The hegemonic $I$ is then forced to renounce its mandate or to abdicate. With the government fallen and the throne overturned, the federation of souls and the absolutist state of the psyche dissolve. As soon as the hegemonic $I$ is weakened, the $I s$ that were previously abandoned or excluded return, strengthened from their exile, and they restore a type of partial power. It can be noted that these Is are not aliens or strangers but, rather, old acquaintances who were repudiated and too often known (even if consciously or unconsciously ignored) and who, up to that point, had been able to express themselves through either dreams or rêveries.

Subsequently, and for most of the twentieth century - until Lacan or Lévi-Strauss - the $I$ was denied unity and continuity, and instead there was assigned to each "dividual" an original and discreet plurality of poles of consciousness. One thinks of Nietzsche, for whom the $I$ is "a plurality of personal forces, of which sometimes one, sometimes the other, comes to the fore as ego, and they look at others as a subject looks at an outside world rich in influences and determinations. The subject is now in one point, now in another." ${ }^{3}$ Formulating the same idea in other ways, he 
asserts that consciousness is formed by a "multiplicity of drives," ${ }^{4}$ just as the body is formed by "a plurality with one sense, a war and a peace, a flock and a shepherd." ${ }^{5}$ Or, again, the $I$ is "a social structure composed of many 'souls' [ Gesellschaftsbau vieler Seelen]," ${ }^{6}$ a unity and a plurality, that excite each other in their interaction.

Ordo amoris poses the problem of love in Augustine and in ancient Christian culture as the capacity of structuring forms of individuality open to change through a remodulation of the passions. Love dissolves the knots that block the will; it heals the conflicts and removes the weight of the past, permitting each person to reformulate and restart their own love from the beginning. The previous state, which in its irreversibility continues to oppress and make us unhappy, no longer blocks faith in the possibility of repeated beginnings. In conformity with the good story, in which "the old is destroyed" and "everything becomes new," the old figure of destiny appears defeated.

Love opens not only towards the future, but also towards the past: the evil committed is endured, the sufferings inflicted and received find their redemption. Reconciling each one with the existence that it has passed through prevents events from petrifying in rancour or remorse. It prevents the will from dividing itself between exacerbated attachment to the memory of old errors or wrongs and the hard-won acceptance of peace with oneself or of forgiveness, which, etymologically, is a strengthened gift, one that is extreme and made by others. Love certainly does not retroactively annul the event, nor even forget it. Judging it to be incomplete, love reopens its processes, re-examines its acts, and modifies its judgments. The healing strength of love - making fluid the viscous, congealed, or hardened past and reconverting it into fresh, available energy - condones guilt and pains that might have seemed inexpiable. Thus, at least temporarily, life begins again: its tears are rewoven, its hostility unvenomed, its worry calmed.

Inventive and disciplined, open and hierarchical, the ordo amoris, in an Augustinian sense, is the result of human freedom and obedience to a divine commandment. Illuminating the way of men through the worries of this world ("squeezed in the press" by the millstone of hunger, war, and death), it guides them towards the beatitude of Paradise. The nonillusory existence of this goal may already be carried out on earth thanks

4 Nietzsche, Kritische Studienausgabe 11: 650.

5 Nietzsche, Also sprach Zarathustra [1883], part 1.4.

6 Nietzsche, Jenseits von Gut und Böse [1886], §19; Engl. trans. Beyond Good and Evil, trans. H. Zimmern (New York, 1954). 
to the irrepressible attraction towards a happiness that is unconditional and without end. In fact, all of us have always aspired to it - paradoxically, even without knowing. Remembered and forgotten to the point of not even remembering having forgotten, it refers back to the presence of a "beauty so old and so new," so far and so near, as to often be understood too late. In fact, sinking into ourselves, we manage to glimpse, through the wrapping of opacity that surrounds us, the enigmatic and inextricable knot of light that pushes the consciousness of every person to God, time to eternity, the body to the spirit, immanence to transcendence, and Exodus to the Kingdom. In fact, God constitutes the most intimate nucleus of the $I$, more internal to myself than I am with respect to my most hidden life. Although not coinciding with me, God is, therefore, more me than I am.

But how can love become an order, in the double sense of a free disposition of the heart and the obedient response to an external commandment? How will it be capable of conserving its spiritual flame, its inventive and nonviolent power, if it is required to comply with the substantial rigidity of an invitation to the imperative of someone - however inclined to mercy and to amnesty for crimes - who does not hide the threat of horrible penalties in the case of rejection? Further, how will it reconcile the realization of the new and the possible with respect for an order already given and willed by God since the creation of the world, even if that was then distorted, with regard to man, by the original sin? And finally, at least for our modern feelings, doesn't love constitute the highest form of spontaneity, the "transgressive" passion par excellence that bends neither to the predictability of order as routine nor to its authoritarian imposition? Does it not, perhaps, in order to exclude the suspicion that it might become an opportunistic fiction, safeguard its nature as an unforeseeable, surplus, and free gift?

Ira: La passione furente (Rage: The Furious Passion) analyses the different manifestations of rage in time and space; its relationship with political and religious power; its natural and cultural origins; its presentation, at the level of reality and the imagination, on the basis of opposing pairs made up of men and divinity, men and women, and men and animals; its decline into forms of historical life and into theoretical reflections that involve the identity and role of individuals and communities. Since antiquity, in fact, there has been imputed to it the temporary loss of the most precious of goods: the light of reason and the capacity for selfcontrol. In its inflamed manifestations, it has been considered a form of blindness or temporary madness that undermines lucidity of the mind and freedom of decision. Those who are victims of it appear "outside of 
themselves," subjugated to another, to a tyrannical interior father who deprives them of the ability to understand and desire.

This is born generally from an unmerited offence one believes one has received, from a burning wound inflicted culpably by others on our own self-respect and our (sometimes exaggerated) self-esteem. More precisely, it stems from the conviction of having been betrayed, insulted, tricked, manipulated, scorned, humiliated, neglected, deprived of due respect, or treated in an unjust or inappropriate way. It arises from the disconsolate or irritating observation of the inadequacy of our behaviour in particular circumstances, from the bitter regret for having wasted opportunities or even life itself. Above all, it depends on ruminating and on impotent recrimination for not having reversed the course of time in order to rectify our conduct, a posteriori, and remedy errors committed.

This passion is an ambivalent indicator of both the level of vulnerability of one's I and, simultaneously, its desire for assertiveness. It sometimes even represents an excess of legitimate defence of personal psychic and physical space and the system of principles and beliefs with which the individual or group identifies. It seems to be associated with the need to preserve, reactively, one's own public image (actually or presumably threatened by the offence) and the need to restore the self-esteem that one believes to have been wounded. It basically concerns the reaffirmation of one's own role, dignity, or authoritativeness in interpersonal or political relationships.

Rage makes up part of the sad passions Spinoza speaks of in his Ethics that - along with hate, envy, or avarice - suppress our will to live or "power of existing." They make us suffer, but they also contain (and Spinoza does not take this into account) an intrinsic compensation, a portion - even if not prevalent - of bitter pleasure, of the satisfaction of getting back, often enjoyed at the level of fantasy. In rage, this compensation is represented from the perspective of a reprisal or revenge that the imagination foresees in a more or less violent way; in hate, by looking forward to the destruction of one's own enemies; in envy, by joy in the misfortune of others; and in avarice, by the enjoyment of contemplating money saved as repayment for the sacrifice of not spending it.

In Western culture, the image of rage is twofold. On one side, it is considered a noble passion of rebellion against offences and injustices, the desire to punish the person believed to have insulted one. On the other, it represents a feared loss of autonomy and judgment. Tradition is divided, therefore, into two branches that have lasted more than two millennia: one that accepts rightful anger but condemns irascibility, the other that rejects every type of anger and asks that one abstain from it completely. 
In the triptych that makes up Geometry of the Passions, Ordo amoris, and Destini personali, as well as in the volume on rage, I tried to elaborate theoretical and ethical models to understand the near and distant bases of the formation of our identity. In all of these cases, I never separated the historical dimension from the theoretical. I wanted to construct what I call crystals of historicity, conceptual formations that are the result of the depositing and structuring over time of events and ideas that undoubtedly change, but according to specific formal and "figural" modes. Thanks to this new Introduction, I hope to have contributed to a better understanding of Geometry of the Passions.

Remo Bodei 